\title{
Thermaerobacter litoralis sp. nov., a strictly aerobic and thermophilic bacterium isolated from a coastal hydrothermal field
}

\author{
Correspondence \\ Reiji Tanaka \\ tanakar@kais.kyoto-u.ac.jp
}

\author{
Reiji Tanaka, Satoshi Kawaichi, Hiroshi Nishimura and Yoshihiko Sako \\ Laboratory of Marine Microbiology, Graduate School of Agriculture, Kyoto University, \\ Kitashirakawa-oiwake, Kyoto 606-8502, Japan
}

\begin{abstract}
A novel thermophilic bacterium, strain $\mathrm{KW}^{\top}{ }^{\top}$, was isolated from a coastal hydrothermal field on the Satsuma Peninsula, Kagoshima Prefecture, Japan. The variably Gram-stained cells were motile rods with flagella, did not form spores and proliferated at $52-78^{\circ} \mathrm{C}$ (optimum, $70^{\circ} \mathrm{C}$ ), pH 5-8 (optimum, pH 7) and $0-4.5 \% \mathrm{NaCl}$ (optimum, $1.0 \%$ ). The novel isolate was a strictly aerobic heterotroph that utilized complex proteinaceous substrates as well as a variety of carboxylic acids and amino acids. The $\mathrm{G}+\mathrm{C}$ content of the genomic DNA was $70 \cdot 8 \mathrm{~mol} \%$. Analysis of $16 \mathrm{~S}$ rRNA gene sequences indicated that strain $\mathrm{KW}^{\top}{ }^{\top}$ is closely related to Thermaerobacter subterraneus $\mathrm{C} 21^{\top}$ (98.4 \% sequence similarity). However, the DNA-DNA hybridization value for strain $\mathrm{KW} 1^{\top}$ and $T$. subterraneus ATCC BAA- $137^{\top}$ was below $46 \%$. On the basis of the molecular and physiological traits of strain $\mathrm{KW} 1^{\top}$, it represents a novel species of the genus Thermaerobacter, for which the name Thermaerobacter litoralis sp. nov. is proposed. The type strain is $\mathrm{KW}^{\top}$ $\left(=\mathrm{JCM} 13210^{\top}=\right.$ DSM $\left.17372^{\top}\right)$.
\end{abstract}

The biodiversity of thermophiles in hydrothermal beaches has been extensively studied at Vulcano and Ischia (Italy) and at Kodakara Jima (Japan) (Stetter, 1996; Hokai et al., 1995). Heterotrophic aerobes belonging to the genera Aeropyrum, Pyrobaculum, Thermus, Rhodothermus and Thermaerobacter (Sako et al., 1996a, b; Völkl et al., 1993; Oshima \& Imahori, 1974; Alfredsson et al., 1979; Takai et al., 1999 ) as well as hydrogen-oxidizers belonging to the genera Aquifex and Hydrogenivirga (Huber et al., 1992; Nakagawa et al., 2004) have been isolated from hydrothermal beaches. These observations indicate that coastal hydrothermal environments with high oxygen concentrations harbour a highly diverse group of marine thermophiles; further exploration of these environments may lead to the discovery of novel thermophilic micro-organisms. Here, we describe the isolation of a novel thermophilic, strictly aerobic bacterium from a coastal hydrothermal beach in Japan.

Sandy sediments and hot fluids were collected from a hydrothermal beach on the Satsuma peninsula, Kagoshima, Japan. The temperature of the vent fluids was $90-95^{\circ} \mathrm{C}$. Samples were stored aerobically at room temperature for $12 \mathrm{~h}$ before incubation. A series of batches of MJYPV medium (Sako et al., 2003) were inoculated with samples of sandy sediment and the $\mathrm{pH}$ was adjusted to $8 \cdot 0$ with $\mathrm{NaOH}$. Some of the batches of MJYPV medium containing these samples became turbid after 1 day of incubation at

The GenBank/EMBL/DDBJ accession number for the 16S rRNA gene sequence of strain $\mathrm{KW}^{\top}{ }^{\top}$ is $\mathrm{AY} 936496$.
$70{ }^{\circ} \mathrm{C}$. To obtain a pure culture, enriched cultures were streaked on to MJYPV plates containing 3\% (w/v) GP-700 agar (Shimizu Shokuhin), which remains solid at temperatures up to $80^{\circ} \mathrm{C}$, and were incubated at $70^{\circ} \mathrm{C}$. Well-defined colonies were selected and streaked onto fresh plates. This procedure was repeated at least three times. The isolate was designated strain $\mathrm{KW}^{\mathrm{T}}$ and its purity was confirmed routinely by microscopy and by repeated partial sequencing of the 16S rRNA gene using PCR primers 27F and 1492R (Nakagawa et al., 2004).

Cells were observed using a differential interference microscope (Eclipse 800 system; Nikon). Negatively stained cells were examined by transmission electron microscopy, as described by Zillig et al. (1990); cells were stained with $1 \%$ (w/v) uranyl acetate and examined using an H-700 electron microscope (Hitachi) at an accelerating voltage of $100 \mathrm{kV}$. The motile cells of strain $\mathrm{KW}^{\mathrm{T}}$ were $1-4 \mu \mathrm{m}$ in length and $0 \cdot 3-0 \cdot 8 \mu \mathrm{m}$ in width. Electron microscopy of negatively stained samples revealed monopolar flagellation (Fig. 1). Cells stained Gram-positive during the early exponential phase and stained Gram-negative during the mid-exponential phase or stationary phase.

The spore-forming ability of the novel isolate was examined at low concentrations of organic compounds (10 and 50\% of the concentrations in the MJYPV medium). However, spores did not form during any growth phase, and targeted segments of the sporulation gene spo0A, which has been used as a probe for spore-forming bacteria, were not 


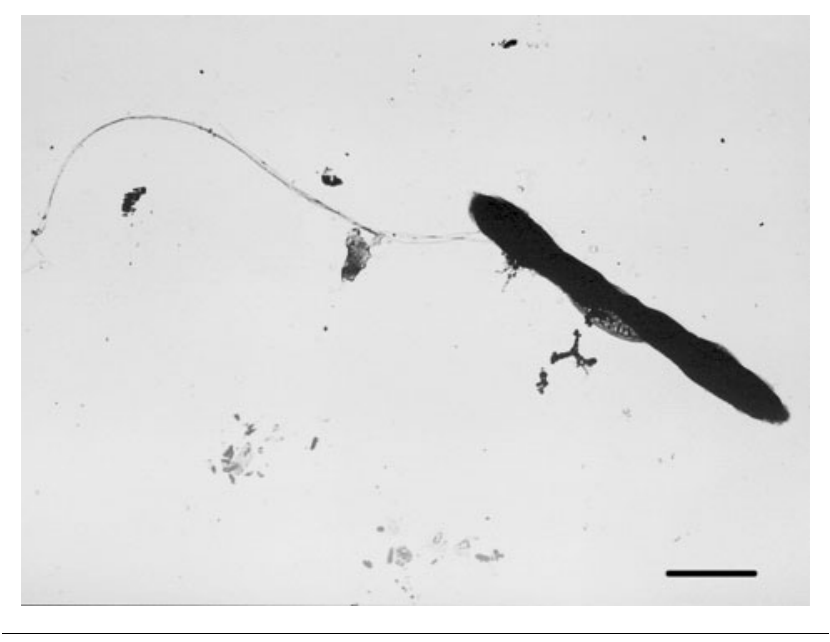

Fig. 1. Transmission electron micrograph of negatively stained cell of strain $\mathrm{KW}^{\top}$. Bar, $1 \mu \mathrm{m}$.

amplified by the PCR (Brown et al., 1994; Brill \& Wiegel, 1997; Nunoura et al., 2002).

Growth of the novel isolate under various conditions was determined by means of direct cell counting, after staining with 4',6-diamino-2-phenylindole (Porter \& Feig, 1980), using an epifluorescence microscope (Eclipse 800 system; Nikon). We determined the effects of various temperatures on growth by cultivating the novel isolate in MJYPV medium (Sako et al., 2003). Strain $\mathrm{KW} 1^{\mathrm{T}}$ grew at $52-78^{\circ} \mathrm{C}$, with an optimum at $70^{\circ} \mathrm{C}$. The strain did not grow at temperatures below $50^{\circ} \mathrm{C}$ or above $80^{\circ} \mathrm{C}$. The effects of $\mathrm{pH}$ and salinity on growth of the isolate were therefore determined at $70{ }^{\circ} \mathrm{C}$. The $\mathrm{pH}$ of MJYPV medium containing $20 \mathrm{mM}$ MES ( $\mathrm{pH} 5 \cdot 0-6 \cdot 0)$, PIPES ( $\mathrm{pH} 6 \cdot 3-7 \cdot 0$ ), HEPES ( $\mathrm{pH} 7 \cdot 3-$ $8 \cdot 0$ ) or Tris ( $\mathrm{pH} 8 \cdot 5$ and above) was adjusted with $\mathrm{H}_{2} \mathrm{SO}_{4}$ or $\mathrm{NaOH}$ at room temperature. After autoclaving, the $\mathrm{pH}$ was examined and readjusted aseptically with $\mathrm{H}_{2} \mathrm{SO}_{4}$ or $\mathrm{NaOH}$ at room temperature if necessary. The $\mathrm{pH}$ values of all media were stable during the cultivation period. The isolate grew at $\mathrm{pH}$ values between $5 \cdot 5$ and $9 \cdot 0$, with an optimum at $\mathrm{pH} 7 \cdot 0$. No growth was detected below $\mathrm{pH} 5 \cdot 0$ or above $\mathrm{pH} 9 \cdot 5$. To determine the effects of salinity on growth, the isolate was incubated in MJYPV medium containing various dilutions of $3 \times$ MJ synthetic seawater (Nakagawa et al., 2004) $(1 \times$ MJ synthetic seawater contains $35 \mathrm{~g}$ sea salts). The isolate grew at $0-4 \cdot 5 \%(\mathrm{w} / \mathrm{v})$ salinity, with an optimum at $1.0 \%$. Growth was not observed at salinities above $5 \cdot 0 \%$. Growth of the isolate was inhibited completely in the presence of $0 \cdot 1 \%(\mathrm{w} / \mathrm{v}) \mathrm{Na}_{2} \mathrm{~S}_{2} \mathrm{O}_{3}$ in MJYPV medium (Sako et al., 1996a) at $70{ }^{\circ} \mathrm{C}$. Other compounds such as $0 \cdot 1 \%$ (w/v) $\mathrm{Na}_{2} \mathrm{SO}_{3}$, $\mathrm{Na}_{2} \mathrm{SO}_{4}$ and cysteine hydrochloride did not affect growth of the isolate, whereas $3 \% \mathrm{~S}^{0}$ inhibited growth completely.

We examined the growth of the novel isolate under anaerobic conditions. Air was replaced with $\mathrm{N}_{2}(100 \mathrm{kPa})$ and cells were applied to $5 \mathrm{ml}$ MJYPV medium in the presence or absence of an electron acceptor such as $0 \cdot 1 \%(\mathrm{w} / \mathrm{v})$ $\mathrm{NaNO}_{3}, \mathrm{Na}_{2} \mathrm{SO}_{3}, \mathrm{NaNO}_{2}$ or $\mathrm{Na}_{2} \mathrm{~S}_{2} \mathrm{O}_{3}$. The strain did not grow under any of the tested anaerobic conditions.

We supplemented MJ synthetic seawater (Sako et al., 2003) with 0.2 and $0.02 \%(\mathrm{w} / \mathrm{v})$ of the following: yeast extract, trypticase peptone, yeast extract and trypticase peptone in combination, gelatin (Sigma), casein (Sigma), Casamino acids (Difco), starch (Wako), D( + )-glucose, sucrose, lactose, maltose, galactose, mannitol, fructose, cellulose, cellobiose, xylose, tartrate, acetate, butyrate, citrate, aminobutyric acid, pyruvate, succinate, malate, lactate, inositol, glycine, isoleucine, valine, serine, proline, lysine, arginine, histidine, threonine, alanine, leucine, methionine, phenylalanine, tryptophan, tyrosine, asparagine, glutamine, glutamate, aspartate and cysteine. Strain $\mathrm{KW}^{\mathrm{T}}$ grew heterotrophically on complex proteinaceous substrates such as yeast extract and trypticase peptone (alone or in combination), gelatin and Casamino acids. The strain also proliferated in the presence of acetate, pyruvate, succinate, malate, butyrate, proline, glycine, methionine, threonine, alanine, glutamine, glutamate and aspartate, but not in the presence of any of the sugars tested. The substrate concentrations $(0 \cdot 2$ and $0.02 \%)$ did not influence the results of these tests.

Genomic DNA of strain $\mathrm{KW}^{\mathrm{T}}$, Thermaerobacter marianensis JCM $10246^{\mathrm{T}}$, Thermaerobacter nagasakiensis JCM $11223^{\mathrm{T}}$ and Thermaerobacter subterraneus ATCC BAA- $137^{\mathrm{T}}$ was isolated as described by Lauerer et al. (1986) and the $\mathrm{G}+\mathrm{C}$ content was determined by HPLC (Tamaoka \& Komagata, 1984) using a DNA-GC kit (Yamasa Shouyu). The $\mathrm{G}+\mathrm{C}$ content of strain $\mathrm{KW} 1^{\mathrm{T}}$ was $70 \cdot 8 \mathrm{~mol} \%$.

The 16S rRNA gene was amplified by means of a PCR using primers 27F and 1492R (Nakagawa et al., 2004) and the PCR product was sequenced directly by deoxynucleotide chain termination using an ABI 373A automated DNA sequencer (Applied Biosystems). The 16S rRNA gene sequence was aligned with a subset of $16 \mathrm{~S}$ rRNA gene sequences obtained from the National Center for Biotechnology Information (http://www.ncbi.nlm.nih.gov) and 1400 bases from each organism were analysed by neighbour joining (Saitou \& Nei, 1987) using BIONJ (Gascuel, 1997). The 16S rRNA gene sequence of strain $\mathrm{KW}^{\mathrm{T}}$ was very similar to those of other Thermaerobacter species $(97 \cdot 3-98 \cdot 4 \%$ similarity), but was not similar to those of any other organisms (Fig. 2).

Purified DNA from the isolate, strain $\mathrm{KW}^{\mathrm{T}}$, was compared with that of T. marianensis JCM $10246^{\mathrm{T}}$, T. nagasakiensis JCM $11223^{\mathrm{T}}$ and T. subterraneus ATCC BAA- $137^{\mathrm{T}}$ by fluorometric DNA-DNA hybridization using photobiotinlabelled DNA, as described by Ezaki et al. (1989). Relatedness values were measured under optimal conditions $\left(T_{\mathrm{m}}-25^{\circ} \mathrm{C}\right)$. The DNA of strain $\mathrm{KW} 1^{\mathrm{T}}$ yielded relatively low hybridization signals with DNA from T. marianensis, T. nagasakiensis and T. subterraneus (38, 44 and $46 \%$ relatedness, respectively). These findings indicated that the novel isolate could be differentiated genotypically from other Thermaerobacter species. 


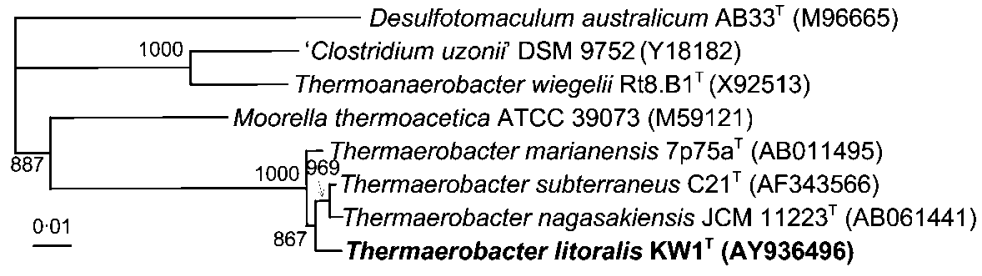

Fig. 2. Neighbour-joining tree showing the phylogenetic position of strain $\mathrm{KW}^{\top}$ and related taxa based on 16S rRNA gene sequences, using 1400 bp sequences in the analysis. Numbers at nodes indicate levels of bootstrap support based on neighbourjoining analyses of 1000 resampled datasets. Bar, 0.01 substitutions per nucleotide position.
Members of the genus Thermaerobacter have been isolated from both hot marine and terrestrial environments. For example, T. marianensis and T. nagasakiensis were respectively isolated from the deep Mariana Trench (Takai et al., 1999) and from fluids in shallow hydrothermal vents in Tachibana Bay, Nagasaki Prefecture, Japan (Nunoura et al., 2002) and T. subterraneus was isolated from a terrestrial environment in the Great Artesian Basin of Australia (Spanevello et al., 2002). The levels of similarity between the $16 \mathrm{~S}$ rRNA gene sequences of strain $\mathrm{KW}^{\mathrm{T}}$ and other Thermaerobacter strains were found to be high, but the phenotypes were quite different (Table 1). For example, strain $\mathrm{KW}^{\mathrm{T}}$ is motile with flagella, whereas $T$. marianensis and T. subterraneus are neither motile nor flagellated. Strain $\mathrm{KW} 1^{\mathrm{T}}$ showed variable Gram-staining, whereas T. subterraneus is Gram-positive; electron microscopic examination of thin sections showed that the latter has a cell wall lacking the outer cell membrane that is typical of Gram-negative species (Spanevello et al., 2002). These organisms also differed in terms of the utilization of carbon sources and in the effects of $\mathrm{pH}$ and phosphate on growth. Several carboxylic acids support the growth of strain $\mathrm{KW}^{\mathrm{T}}$ but not that of either T. nagasakiensis or T. subterraneus. Thiosulfate inhibited the growth of strain $\mathrm{KW}^{\mathrm{T}}$, but not that of other Thermaerobacter species. Notably, the growth of $T$. nagasakiensis is stimulated by $\mathrm{S}^{0}$ and thiosulfate. Finally, DNA-DNA hybridization indicated that strain $\mathrm{KW}^{\mathrm{T}}$ is genotypically different from other Thermaerobacter species. On the basis of these physiological and genetic properties, we propose that this organism represents a novel species, for which we propose the name Thermaerobacter litoralis sp. nov.

\section{Description of Thermaerobacter litoralis sp. nov.}

Thermaerobacter litoralis (li.to.ra' lis. L. masc. adj. litoralis of the shore).

Cells are Gram-reaction-variable, motile, flagellated rods $1-4 \mu \mathrm{m}$ long and $0 \cdot 3-0 \cdot 8 \mu \mathrm{m}$ wide. Forms colonies on agar plates without forming spores and grows at $52-78{ }^{\circ} \mathrm{C}$ (optimum, $70{ }^{\circ} \mathrm{C}$ ) and $\mathrm{pH} 5 \cdot 5-9 \cdot 0$ (optimum, $\mathrm{pH} \mathrm{7 \cdot 0)}$ in the presence of $0-4 \cdot 5 \% \mathrm{NaCl}$ (optimum $1 \cdot 0 \%$ ). Growth is heterotrophic in the presence of proteinaceous complex substrates, gelatin, Casamino acids, acetate, pyruvate,

Table 1. Characteristics of strain $\mathrm{KW}^{\top}$ and type strains of other Thermaerobacter species

Data are from this study and from Takai et al. (1999), Nunoura et al. (2002) and Spanevello et al. (2002).

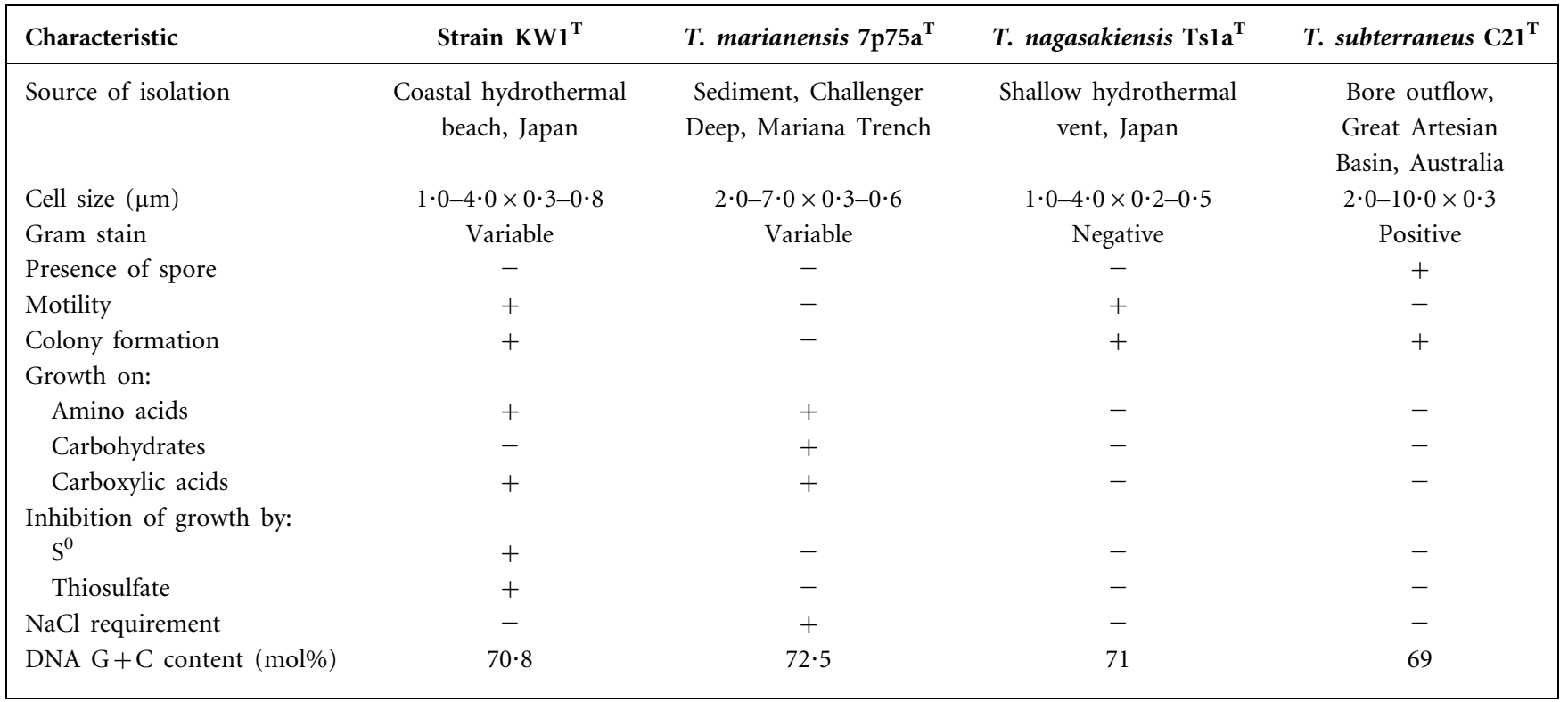


succinate, malate, butyrate, proline, glycine, methionine, threonine, alanine, glutamine, glutamate and aspartate. Growth is inhibited by thiosulfate and $\mathrm{S}^{0}$. The $\mathrm{G}+\mathrm{C}$ content of the genomic DNA of the type strain is $70.8 \mathrm{~mol} \%$ (HPLC).

The type strain, $\mathrm{KW}^{\mathrm{T}}$ ( = JCM $13210^{\mathrm{T}}=\mathrm{DSM} 17372^{\mathrm{T}}$ ), was isolated from a coastal hydrothermal beach on the Satsuma peninsula, Kagoshima Prefecture, Japan.

\section{Acknowledgements}

We are grateful to Dr Tomoo Sawabe (Graduate School of Fisheries, Hokkaido University, Japan) for the electron micrographs. This work was supported by a JSPS Research Fellowship (no. 15-04791) for Young Scientists from the Ministry of Education, Culture, Sports, Science and Technology of Japan.

\section{References}

Alfredsson, G. A., Kristjansson, J. K., Hjörleifsdottir, S. \& Stetter, K. O. (1979). Rhodothermus marinus, gen. nov., sp. nov, a thermophilic, halophilic bacterium from submarine hot springs in Iceland. J Gen Microbiol 134, 49-68.

Brill, J. A. \& Wiegel, J. (1997). Differentiation between spore-forming and asporogenic bacteria using a PCR and Southern hybridization based method. J Microbiol Methods 31, 29-36.

Brown, D. P., Genova-Raeva, L., Green, B. D., Wilkinson, S. R., Young, M. \& Youngman, P. (1994). Characterization of spoOA homologues in diverse Bacillus and Clostridium species identifies DNAbinding domain. Mol Microbiol 14, 411-426.

Ezaki, T., Hashimoto, Y. \& Yabuuchi, E. (1989). Fluorometric deoxyribonucleic acid-deoxyribonucleic acid hybridization in microdilution wells as an alternative to membrane filter hybridization in which radioisotopes are used to determine genetic relatedness among bacterial strains. Int J Syst Bacteriol 39, 224-229.

Gascuel, O. (1997). BIONJ: an improved version of the NJ algorithm based on a simple model of sequence data. Mol Biol Evol 14, 685-695.

Hokai, T., Nishijima, M., Miyashita, H. \& Maruyama, T. (1995). Dense community of hyperthermophilic sulfur-dependent heterotrophs in a geothermally heated shallow submarine biotope near Kodakara-Jima Island, Kagoshima, Japan. Appl Environ Microbiol 61, 1931-1937.

Huber, R., Wilharm, T., Huber, D. \& 7 other authors (1992). Aquifex pyrophilus gen. nov., sp. nov. represents a novel group of marine hyperthermophilic hydrogen-oxidizing bacteria. Syst Appl Microbiol 15, 340-351.

Lauerer, G., Kristjansson, J. K., Langworthy, T. A., König, H. \& Stetter, K. O. (1986). Methanothermus sociabilis sp. nov., a second species within the Methanothermaceae growing at $97^{\circ} \mathrm{C}$. Syst Appl Microbiol 8, 100-105.

Nakagawa, S., Nakamura, S., Inagaki, F., Takai, K., Shirai, N. \& Sako, Y. (2004). Hydrogenivirga caldilitoris gen. nov., sp. nov., a novel extremely thermophilic, hydrogen- and sulfur-oxidizing bacterium from a coastal hydrothermal field. Int J Syst Evol Microbiol 54, 2079-2084.

Nunoura, T., Akihara, S., Takai, K. \& Sako, Y. (2002). Thermaerobacter nagasakiensis sp. nov., a novel aerobic and extremely thermophilic marine bacterium. Arch Microbiol 177, 339-344.

Oshima, T. \& Imahori, K. (1974). Description of Thermus thermophilus (Yoshida and Oshima) comb. nov., a nonsporulating thermophilic bacterium from Japanese thermal spa. Int J Syst Bacteriol 24, 102-112.

Porter, K. G. \& Feig, Y. S. (1980). The use of DAPI for identifying and counting microflora. Limnol Oceanogr 25, 943-948.

Saitou, N. \& Nei, M. (1987). The neighbor-joining method: a new method for reconstructing phylogenetic trees. Mol Biol Evol 4, 406425 .

Sako, Y., Nomura, N., Uchida, A., Ishida, Y., Morii, H., Koga, Y., Hoaki, T. \& Maruyama, T. (1996a). Aeropyrum pernix gen. nov., sp. nov., a novel aerobic hyperthermophilic archaeon growing at temperatures up to $100^{\circ} \mathrm{C}$. Int J Syst Bacteriol 46, 1070-1077.

Sako, Y., Takai, K., Ishida, Y., Uchida, A. \& Katayama, Y. (1996b). Rhodothermus obamensis sp. nov., a modern lineage of extremely thermophilic marine bacteria. Int J Syst Bacteriol 46, 1099-1104.

Sako, Y., Nakagawa, S., Takai, K. \& Horikoshi, K. (2003). Marinithermus hydrothermalis gen. nov., sp. nov., a strictly aerobic, thermophilic bacterium from a deep-sea hydrothermal vent chimney. Int J Syst Evol Microbiol 53, 59-65.

Spanevello, M. D., Yamamoto, H. \& Patel, B. K. C. (2002). Thermaerobacter subterraneus sp. nov., a novel aerobic bacterium from the Great Artesian Basin of Australia, and emendation of the genus Thermaerobacter. Int J Syst Evol Microbiol 52, 795-800.

Stetter, K. O. (1996). Hyperthermophilic prokaryotes. FEMS Microbiol Rev 18, 149-158.

Takai, K., Inoue, A. \& Horikoshi, K. (1999). Thermaerobacter marianensis gen. nov., sp. nov., an aerobic extremely thermophilic marine bacterium from the $11000 \mathrm{~m}$ deep Mariana Trench. Int J Syst Bacteriol 49, 619-628.

Tamaoka, J. \& Komagata, K. (1984). Determination of DNA base composition by reversed-phase high-performance liquid chromatography. FEMS Microbiol Lett 25, 125-128.

Völkl, P., Huber, R., Drobner, E., Rachel, R., Burggraf, S., Trincone, A. \& Stetter, K. O. (1993). Pyrobaculum aerophilum sp. nov., a novel nitrate-reducing hyperthermophilic archaeum. Appl Environ Microbiol 59, 2918-2926.

Zillig, W., Holz, I., Janekovic, D. \& 7 other authors (1990). Hyperthermus butylicus, a hyperthermophilic sulfur-reducing archaebacterium that ferments peptides. J Bacteriol 172, 3959-3965. 